\title{
Life on the Edge. Peter Danckwerts GC MBE fRS BRAVE,SHY, BRILLIANT
}

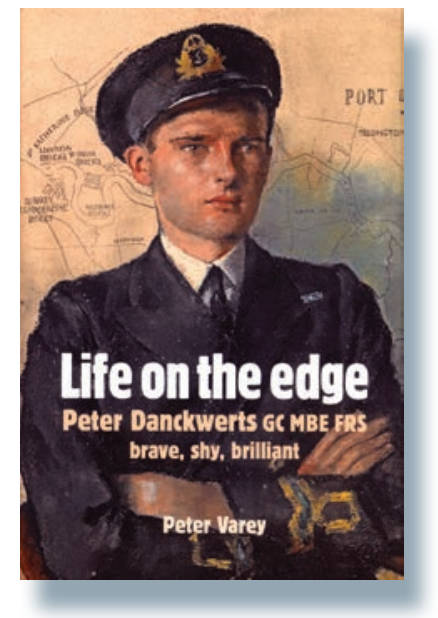

O ano de 2012 fez vir a lume uma biografia de Peter Danckwerts: "Life on the Edge. Peter Danckwerts GC MBE FRS brave, shy, brilliant", da autoria de Peter Varey. Em 1940, Peter era um jovem graduado em Química no Balliol College da Universidade de Oxford. Ao tempo, a Química oxfordiana era demasiado descritiva e desprovida de matemática e física. Dizia-se que se o estudante de química encontrasse num livro de texto uma diferencial virava a página e se encontrasse um sinal de integral fechava o livro.

A obra inicia-se com um Danckwerts de 23 anos a oferecer-se à Royal Navy para participar no esforço de guerra. Foi colocado no serviço de minas e armadilhas, onde teve formação para a desativação de bombas provenientes dos bombardeamentos da aviação alemã na Grã-Bretanha. A sua ação foi tão meritória e corajosa que lhe valeu ser condecorado com a George Cross e, posteriormente, recebeu a Order of the British Empire (MBE). A biografia faz-nos percorrer o ambiente da guerra em Inglaterra e depois vê-o mobilizado para Gibraltar e posteriormente para a Sicília, onde ficou ferido e teve uma lenta recuperação da sua perda de consciência. A perspetiva de Peter é que na sua atividade tinha ocasionalmente momentos de apreensão e medo, mas nada se comparava com quem estivesse nas frentes de combate, onde um tal ambiente era quase

\footnotetext{
* Departamento de Química

Universidade de Coimbra

E-mail: sformosinho@qui.uc.pt
}

\author{
SEBASTIÃO J. FormOSINHO*
}

\author{
Autor: Peter Varey \\ Editora: PVF Publications \\ N. ${ }^{\circ}$ páginas: 378 \\ ISBN: 978-0-95384420-2-9
}

permanente. Como refere, as bombas alemãs eram letais, mas desenhadas com uma lógica perfeita, que uma vez compreendida permitia lidar com elas sem perigo de maior. Já as italianas tinham designs um pouco lunáticos, o que as tornavam mais imprevisíveis, mas não eram letais.

Aos 27 anos encontra-se desmobilizado à procura de um emprego industrial, passado seis anos da sua estadia numa empresa de argilas e barros. Todavia, conseguiu uma bolsa de estudos para ir estudar para o MIT num curso de dois anos de engenharia química. Regressado a Inglaterra, e ante a dificuldade de regressar a um emprego industrial, entrou em contacto com o Diretor do recém-criado Departamento de Engenharia Química da Universidade de Cambridge, Terence Fox. O Departamento foi fruto do empenho de John Oriel, executivo da Shell, e Ronald Norrish, professor de química em Cambridge. Ao tempo, o Departamento ainda não dispunha de instalações. Aliás, Departamento que era visto com apreensão pelos outros Departamentos mais antigos, "não fosse emitir fumos corrosivos".

Na "boémia de Cambridge" vamos cruzar com nomes como George Porter, Francis Crick, James Watson, Kenneth Denbigh e tantos outros, dentro e fora de Cambridge, como Dainton, Peter Gray, Fred Hoyle, Alexander Todd e Alfred Ubbelohde. Mas também os trabalhos de alguns dos seus estudantes de doutoramento, entre eles Armando
Tavares da Silva, hoje professor jubilado da Universidade de Coimbra, e de uma seleção de colaboradores. Para a comunidade de académicos portugueses da década de 60 e 70 , que fez a sua formação doutoral ou pós-doutoral em universidades britânicas, o livro traz inúmeras memórias, historietas académicas, pormenores de bastidores e da ribalta da ciência.

Em apêndice, a obra traz um bónus, precisamente dedicado a Tavares da Silva, "Sadi Carnot, precocious polymath", um desafio a historiadores e filósofos da Termodinâmica. Quiçá o mais relevante fruto das investigações de Danckwerts, em "neglected corners of science", após aposentação. Deixou um escrito sobre os estudos de Carnot, pois entendia não haver ele recoIhido todo o crédito que merecia. Não o conseguiu publicar em vida, mas o autor da presente obra dá-o a lume. Ainda bem que os caminhos da ciência não são os de uma dogmática insuperável.

O jovem e ainda desconhecido Sadi Carnot teve de assumir a linguagem do calórico, se bem que nele não acreditasse. Mas alcançou uma formulação da 1. ${ }^{\mathrm{a}}$ lei da termodinâmica, apesar de ao tempo ainda não ter sido formulado o conceito de energia. Alcançou uma estimativa para o "equivalente mecânico do calor (calórico)" pelo menos uns 10 anos antes das experiências de Joule.

A obra dispõe ainda de um índice temático e onomástico muito abrangente. 